\title{
THE RHIGONEMATIDA (NEMATODA) OF DIPLOPODS : reclassification and its cladistic representation
}

\author{
M. L. ADAMSON* and D. VAN WAEREBEKE**
}

SUMMARY. Morphological variation in the Rhigonematida (Nematoda) is reviewed with the aim of identifying evolutionary trends to construct a reclassification. The order is divided into two superfamilies, namely the Rhigonematoidea and the Ransomnematoidea, and a cladistic representation of the generic relationships is given for each. The Rhigonematoidea includes the Rhigonematidae with Rhigonema, Xustrostoma, Obainia and Glomerinema, and the Ichthyocephalidae with Ichthyocephalus, Paraichthyocephalus and Ichthyocephaloides. The Ransomnematoidea includes the Ransomnematidae with Ransomnema, the Hethidae wilh Heth, and the Carnoyidae with Carnoya, Rondonema, Urucuia, Raonema, Clementeia, Brumplaemilius and Waerebekeia. Geographical and host distributions are reviewed and it is suggested that Rhigonema may be a paraphyletic group including primitive members of several different lineages.

\section{Les Rhigonematida (Nematoda) de Diplopodes : reclassification et schéma cladistique.}

RÉSUMÉ. Cet article présente une mise au point sur la morphologie comparée des Rhigonematida (Nematoda) et indique les directions évolutives utilisées pour construire une reclassification du groupe. I'ordre se divise en deux superfamilles, les Rhigonematoidea et les Ransomnematoidea, et un schéma cladistique des genres est présenté pour chacune d'entre elles. Les Rhigonematoidea renferment les Rhigonematidae avec les genres Rhigonema, Xustrostoma, Obainia and Glomerinema, et les Ichthyocephalidae avec les genres Ichthyocephalus, Paraichthyocephalus et Ichthyocephaloides. Les Ransomnematoidea renferment les Ransomnematidae avec le genre Ransomnema, les Hethidae avec le genre Heth et les Carnoyidae avec les genres Carnoya, Rondonema, Urucuia, Clementeia, Raonema, Brumptaemilius et Waerebekeia. I e spectre d'hôtes et la répartition gréographique des genres sont discutés, et il est suggéré que Rhigonema est un groupe paraphylétique comprenant des formes primitives de plusieurs lignées de Rhigonematidae.

\section{Introduction}

Two major groups of nematodes parazite the posterior intestine of the Diplopoda, namely rhigonematids and thelastomatids. Thelastomatids are clearly members of

* Laboratoire de Zoologie (Vers) et École Pratique des Hautes Etudes, Muséum National d'Histoire Naturelle, 61, rue Buffon, F 75231 Paris Cedex 05.

** Office de Recherche Scientifique et Technique d'Outre-Mer, Laboratoire de Zoologie (Vers), Muséum National d'Histoire Naturelle, 61, rue Buffon, F 75231 Paris Cedex 05.

Accepté le I I février 1985 . 
the Oxyurida but the systematic affiliations of rhigonematids are uncertain. Recent studies (Adamson, 1981 ; Inglis, 1983 ; Adamson and van Waerebeke, 1984a) support Chitwood's (1932) contention that rhigonematids are fundamentally distinct from thelastomatids and other Oxyurida and Inglis (1983) treats them as a suborder of the Ascaridida.

Existing classifications of rhigonematids (Kloss, 1960 ; Skrjabin, Schikhobalova and Lagadovskaya, 1966 ; Poinar, 1977) are inadequate on several grounds : they use taxa which include thelastomatids; they employ many families and/or subfamilies but say little of the interrelationships of these taxa; they were constructed when our knowledge of the group was limited and often make use of characters of dubious value.

Recent studies have greatly increased our understanding of the group and the present communication reviews comparative morphology in rhigonematids with the aim of identifying evolutionary trends to construct and justify a new classification. A cladistic representation of proposed phylogenies within the group is given; host and geographic distributions of the genera are reviewed and the place of rhigonematids in the origins of nematode parasitism is discussed.

\section{Proposed classification}

For reasons that we will elaborate below we do not follow Inglis (1983) in including rhigonematids in the Ascaridida. Instead, we follow an earlier proposal (Adamson, 1981) and treat these nematodes as an order, the Rhigonematida. It is divided into two superfamilies, the Rhigonematoidea and the Ransomnematoidea (Table I).

TABLE I. - Proposed reclassification of the order Rhigonematida.

\begin{tabular}{|c|c|c|}
\hline \multirow[t]{2}{*}{ Rhigonematoidea } & Rhigonematidae & $\begin{array}{l}\text { Rhigonema Cobb, } 1898 \\
\text { Obainia Adamson, } 1983 \\
\text { Xustrostoma Adamson and van Waerebeke, } \\
\quad 1984 \\
\text { Glomerinema van Waerebeke, } 1985\end{array}$ \\
\hline & Ichthyocephalidae & $\begin{array}{l}\text { Ichthyocephalus Artigas, } 1926 \\
\text { Paraichthyocephalus Travassos and Kloss, } \\
1958 \\
\text { Ichthyocephaloides Hunt and Sutherland, } 1984\end{array}$ \\
\hline \multirow[t]{3}{*}{ Ransomnematoidea } & Ransomnematidae & Ransomnema Artigas, 1926 \\
\hline & Hethidae & Heth Cobb, 1898 \\
\hline & Carnoyidae & $\begin{array}{l}\text { Carnoya Gilson, } 1898 \\
\text { Rondonema Artigas, } 1926 \\
\text { Clementeia Artigas, } 1930 \\
\text { Brumptaemilius Dollfus, } 1952 \\
\text { Urucuia Kloss, } 1961 \\
\text { Raonema Kloss, } 1965 \\
\text { Waerebekeia Adamson and Anderson, } 1985\end{array}$ \\
\hline
\end{tabular}


Our classification differs little from that of Kloss (1960). We retain the families Rhigonematidae, Ichthyocephalidae, Ransomnematidae, Hethidae and Carnoyidae. The major differences lies in the fact that we oppose the first two families which make up the Rhigonematoidea, to the last three which constitute the Ransomnematoidea.

We recognize the following synonymies : Ruizia Travassos and Kloss, 1958; Dudekemia Artigas, 1930 and Haplacis Baylis and Daubney, 1926 are synonyms of Rhigonema Cobb, 1898 (see Dollfus, 1952 ; Adamson, 1983d) ; Dudekemnema Skrjabin, Schikhobalova and Lagodovskaya, 1966 is a synonym of Ransomnema Artigas, 1929 (see Adamson, 1983a) ; Pararondonema Travassos and Kloss, 1960 and Angranema Travassos, 1949 are synonyms of Rondonema Artigas, 1926 (see Adamson, 1983b).

\section{Morphology and evolutionary trends}

This section is a synthesis of information presented in Osche (1960), Travassos and Kloss (1960, 1965), Kloss (1965), Rao and Kumari (1967), van Waerebeke (1984, 1985a, 1985b), van Waerebeke, Adamson and Kermarrec (1984), Hunt and Sutherland (1984), Adamson (1981, 1982, 1983a, 1983b, 1983c, 1983d, 1983e, 1983f, 1984a, 1984b), Adamson and van Waerebeke (1984a, 1984b, 1985), Adamson and Zaman (1984) and Adamson and Anderson (1985).

Primitive states of characters in each superfamily are determined using freeliving rhabditids as an out-group.

\section{Labial Structures and Oral Opening}

We consider both superfamilies to have arisen from six-lipped ancestors with hexagonal oral openings.

Lips are absent in the Rhigonematoidea. The oral opening is subtriangular in the Rhigonematidae but forms a lateral slit in the Ichthyocephalidae (fig. 1). In Rhigonema and Glomerinema the three sides of the oral opening are about equal whereas in Obaina and Xustrostoma the dorsal side is reduced and the oral opening is dorsoventrally elongate.

Aside from Ransomnema the Ransomnematoidea display a pronounced sexual dimorphism in labial structures, the male exhibiting the more primitive pattern. In all genera lips are reduced (at least in number) and/or absent. In males of the Carnoyidae, Carnoya and Brumptaemilius there are one dorsal and two subventral lips and the oral opening forms a triangle whose apices are subdorsal and ventral in position. In males of Rondonema there are no lips and the oral opening is dorsoventrally elongate ; in those of Waerebekeia dorsal and ventral lips surround a laterally elongate oral opening. Females of the Carnoyidae lack lips and the oral opening is subcircular.

Three lips are present in Ransomnema ; they are ventral and subdorsal and the corners of the subtriangular oral opening are dorsal and subventral in position. This pattern may have evolved directly from a six-lipped pattern but we treat it as a 

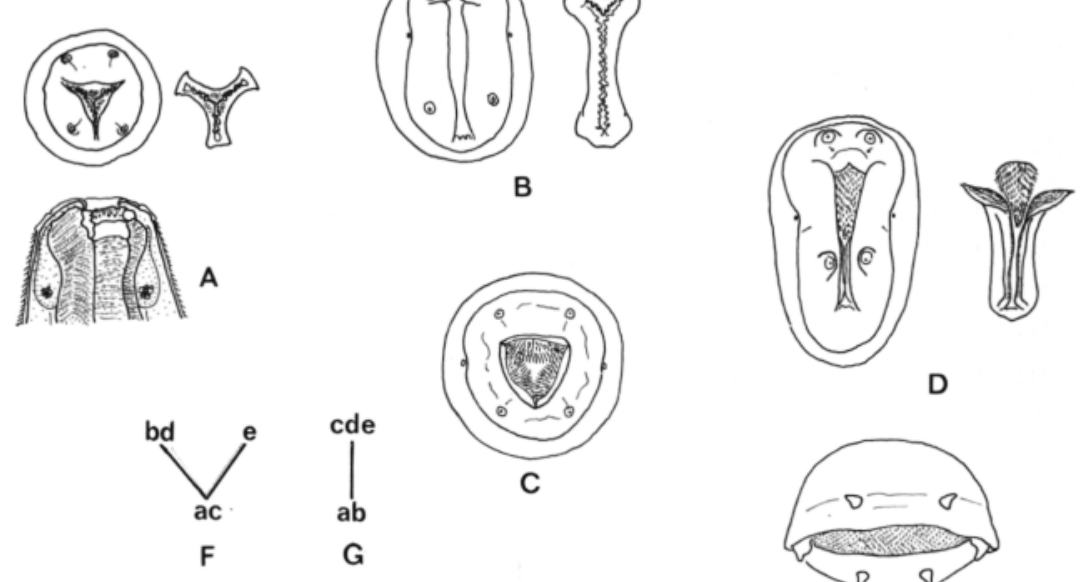

RHIGONEMATOIDEA
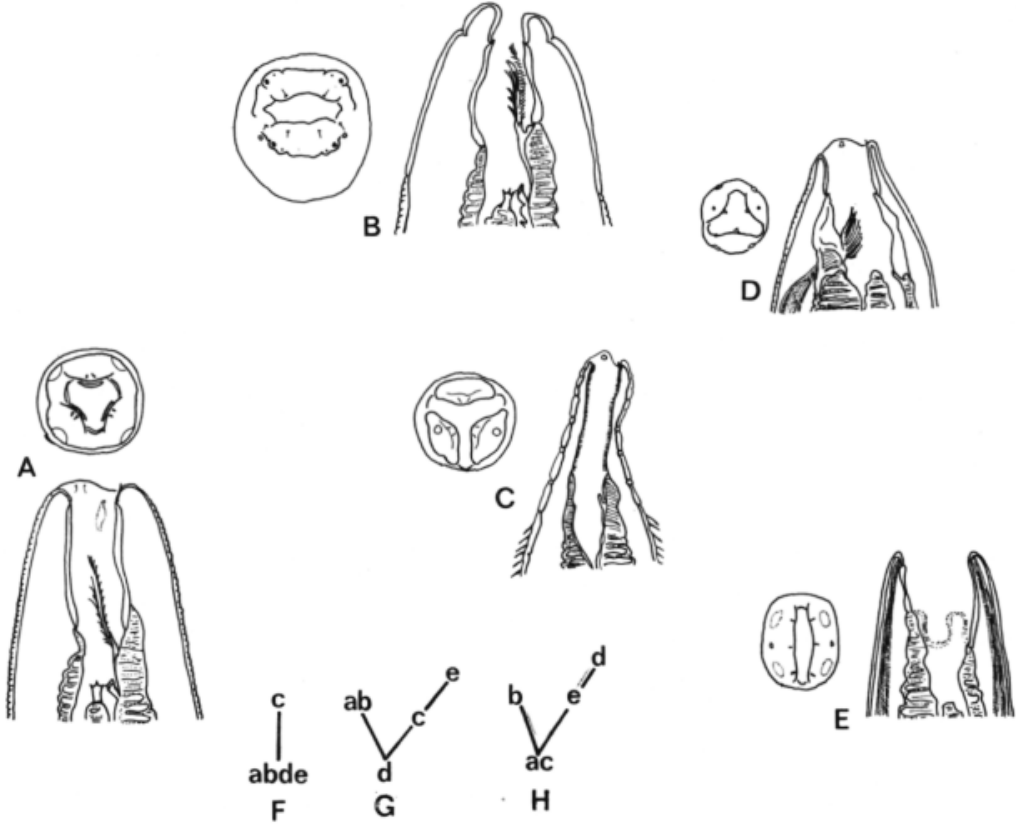

RANSOMNEMATOIDEA

FIG. I. - Variations in cephalic structures and stoma in the Rhigonematida.

Rhigonematoidea : A, Rhigonema; B, Obainia ; C, Glomerinema; D, Xustrostoma; E, Ichthyocephalidae ; $\mathrm{F}$ and $\mathrm{G}$, phylogenetic trees based on characters 3 and 7 respectively.

Ransomnematoidea : A, Brumptaemilius; B. Waerebekeia ; C, Carnoya; D, Ransomnema; E, Rondonema; F, G and H, phylogenetic trees based on characters 2,3 and I r respectively. 
secondary inversion of a Brumptaemilius-like three-lipped pattern. In males of Heth there are no lips and the oral opening is dorsoventrally elongate as in Rondonema. In females, highly developed lateral pseudolabia expand anteriorly to form large plates with pectinate outer edges.

\section{Cephalic Papillae}

The primitive complement of papillae in parasitic nematodes consists of six inner and six outer labial, and four cephalic papillae. In the Rhigonematoidea the lateral outer labial papillae are absent and the submedian outer labial papillae are fused to varying degrees with the cephalic papillae. These form mammiliform structures in the Rhigonematidae and conical structures in the Ichthyocephalidae. Inner papillae may be reduced to varying degrees depending on the species.

The complete complement of papillae occurs in one member of the Ransomnematoidea, namely Brumptaemilius justini Adamson and Anderson, 1985. In other members of the superfamily the lateral outer labial papillae are absent. In females of the Carnoyidae the submedian outer labial papillae are fused with the cephalic papillae to form four semispherical circumoral protuberances.

\section{Buccal Capsule and Cavity}

According to Chitwood (1950b) the buccal cavity of a typical rhabditid consists of a cheilostome or lip cavity, a protostome and a telostome which is partially surrounded by œsophageal tissue.

In the Rhigonematoidea the protostome and telostome are fused and completely surrounded by osophageal tissue. In the Rhigonematidae the buccal capsule takes the form of three sclerotized plates which articulate to form a jaw-apparatus (fig. 1). In Rhigonema and Obaina the plates have tooth-like excrescences and tiny bosses on their luminal surfaces whereas in Glomerinema and Xustrostoma each plate is covered with rows of tiny spines. Primitively, the three plates are identical but in Obaina the dorsal plate is reduced and in Xustrostoma it is laterally compressed. In the Ichthyocephalidae the buccal capsule lines much of the œsophageal corpus and consists of dorsal and ventral cuticular plates bearing rows of tiny spines.

The Ransomnematoidea are characterized by the presence of three cuticular projections at the base of the protostome which we refer to as metastomal projections (see Osche, 1960 for a discussion of the occurrence of these structures throughout the Nematoda). These may be reduced or absent in females but some vestige of them always remains in males. We consider the most primitive conformation in the superfamily to consist of a stalk upon which lamellae are arranged like petals on a flower ( fig. 2). Such metastomal projections occur in Ransomnema, males of Heth, and probably those of Clementeia. In general the evolutionary trend has been towards reduction but in males of Brumptaemilius and Waerebekeia they are hypertrophied.

A second evolutionary trend in the buccal capsule of the Ransomnematoidea is towards lengthening. The Brumptaemilius males serves as an example of the primitive type : the buccal capsule consists of a short cheilostome, an urceolate protostome and a telostome partially surrounded by œesophageal tissue. A similar conformation occurs 

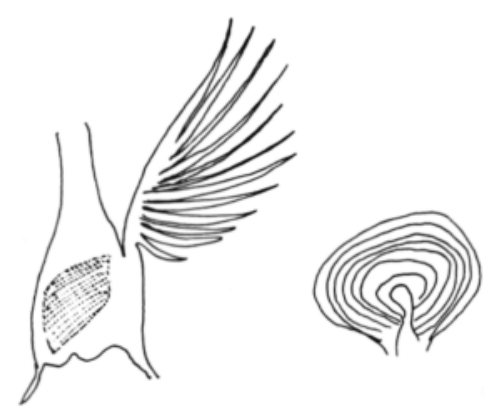

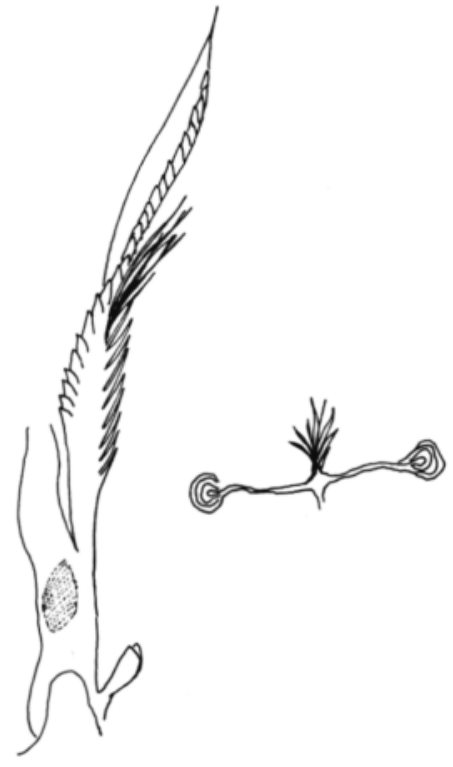

B

\begin{abstract}
A
FIG. 2. -- Schematic representation of metastomal modifications in the Ransomnematoidea. A, lateral and apical views of Ransomnema-type. B, lateral and apical views of Brumplaemilius-type.
\end{abstract}

in Ransomnema and in males of Heth, Waerebekeia and Rondonema, and probably also those of Raonema and Clementeia. In male Carnoya the protostome takes the form of a long tube of striated cuticle and this tendency is carried further in female Carnoyidae where the base of the buccal capsule lies some distance down the oesophagus at the junction between the narrow and broad portions of the corpus. The buccal capsule is also secondarily lengthened in female $H e t h$ but this is accomplished by the encorporation of a long tubular cuticular segment posterior to the telostome and is therefore an instance of convergence.

Oesophagus (fig. 3)

The oesophagus of a typical Rhabditidae consists of a corpus with a posterior swelling, a long cylindrical isthmus and a valved bulb.

In the Rhigonematoidea the corpus is robust ; it is clavate and relatively long in Rhigonema but longitudinally compressed in Obaina, Xustrostoma and Glomerinema, and forms an ovoid mass around the buccal capsule in the Ichthyocephalidae. The isthmus is reduced in the Rhigonematidae and this is most pronounced in Rhigonema ; it is slightly reduced in Ichthyocephalus and Ichthyocephaloides. The bulb is hypertrophied in Obainia, Glomerinema and Xustrostoma. 


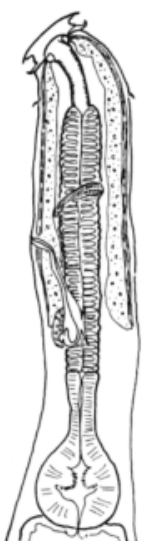

B

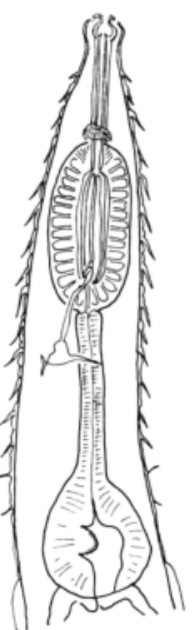

C

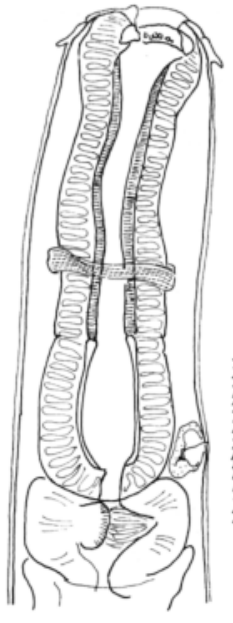

D

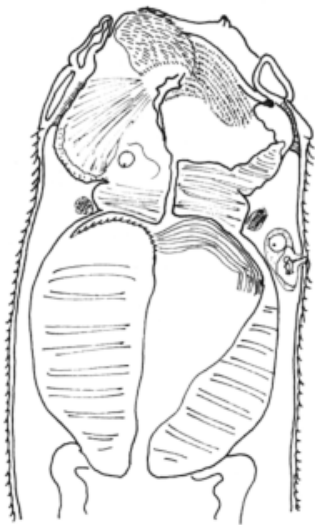

$\mathrm{E}$

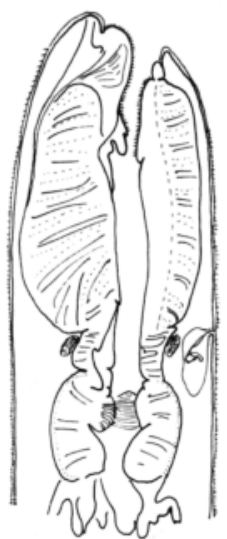

$\mathrm{F}$

FIG. 3. - Variation in oesophageal morphology in the Rhigonematida.

A, male Heth ; B, female Heth ; C, female Carnoya; D, Rhigonema;

E, Xustrostoma; F, Ichthyocephalus.

In both sexes of Ransomnema and in males and larvae of the other Ransomnematoidea the corpus is spindle shaped and distincly set off from the isthmus and bulb. In females of Heth the corpus is slightly modified being roughly cylindrical and in females of the Carnoyidae it is divided into narrow anterior and broad posterior portions.

\section{Excretory System}

The excretory system is $\mathrm{H}$-shaped in both superfamilies. However the terminal duct is vesicular in the Rhigonematoidea whereas the Ransomnematoidea have retained the tubular terminal duct.

\section{Female Reproductive System ( fig. 4)}

The reproductive system of female Rhabditidae characteristically consists of a median vulva and a short, poorly muscularized vagina leading to amphidelphic uteri and reflexed ovaries.

The vagina is generally long and muscular in the Rhigonematoidea; it may include a more glandular vaginal chamber, or a blind vaginal diverticulum. A well differentiated oval seminal receptacle is present. Ichthyocephaloides is monodelphic as a result of complete atrophy of the posterior reproductive horn.

The Ransomnematoidea are monodelphic and digonant, and the vagina is well muscled and long. In Ransomnema the vulva is markedly posterior to midbody and the vagina leads anteriorly to the uterus. The short pyriform ovaries are opposed and reflexed; one opens into the posterior end of the uterus, adjacent to the vaginal 
opening, and the other opens into the anterior end of the uterus. The vulva is also posterior to midbody in Heth; the vagina leads anteriorly through the uterus to a single oval seminal receptacle from which leave two oviducts and parallel ovaries. In the Carnoyidae the vulva lies about midway between the cephalic extremity and the anus. The most primitive pattern is exhibited by Carnoya ; the vagina runs posteriorly from the vulva to a posteriorly directed uterus from which two reflexed oviducts lead anteriorly to parallel anteriorly directed ovaries. The pattern is similar in other Carnoyidae except that the vagina leads anteriorly before flexing posteriorly to join the uterus.

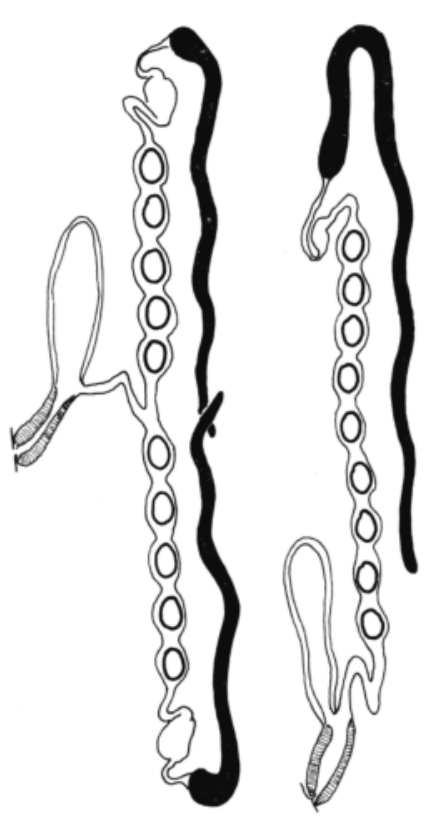

A

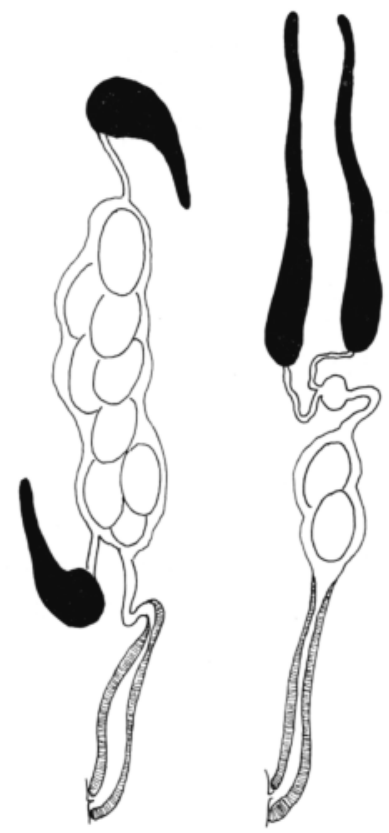

C
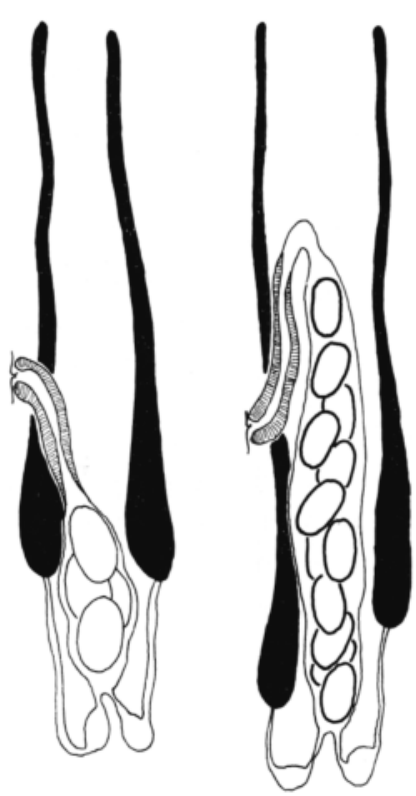

$\mathrm{E}$
$\mathrm{F}$

FIG. 4. - Variations in female reproductive morphology in the Rhigonematida. A, rhigonematoid-type; a vaginal sac has been included but may be absent depending on the species; B, Ichthyocephaloides; C, Ransomnema ; D. Heth; E, Carnoya ; F, Brumptaemilius/ Waerebekeia/Rondonema/Raonema/Urucuia.

\section{Egg Morphology}

The rhabditid egg is surrounded by a thin flexible membranous shell. Eggs in the Rhigonematoidea have a thick smooth shell ; the thickness of the shell is probably due to a highly developed chitinous layer. In some members of the Ransomnematoidea (Ransomnema, Heth and Carnoya) the egg shell is thin and flexible like that in rhabditids. In Rondonema and Urucuia the shell is thin but relatively inflexible ; in Brumptaemilius, Waerebekeia and probably also in Raonema the egg shell is thickened by the presence of a sculptured outer protein layer. 


\section{Male Reproductive Structures}

- Caudal Papillae (fig. 5)

Osche (1958) established homologies between the caudal papillae of Rhabditis and the bursal rays of the Strongylida, and Chabaud and Petter (1961) extended these homologies to include the Ascaridida and Spirurida. According to the latter authors, primitively there are ten pairs and one unpaired caudal papillae of which three pairs (the first, fourth and eigth) are sublateral to subdorsal in position.

The most primitive papilla pattern in the Rhigonematoidea is exhibited by Xustrostoma, Obainia and African and Indian Rhigonema; the full complement is often present (there may be supernumerary pairs) and three sublateral pairs exist. In Glomerinema, Rhigonema from the New World and Pacific region, and the Ichthyocephalidae, the first, fourth and eighth papilla pairs are subventral and the number of papillae may be reduced. Ichthyocephaloides apparently has supernumerary papillae.

The number of caudal papillae is reduced to seventeen or fewer in the Ransomnematoidea. In Brumptaemilius, Raonema, Waerebekeia and Urucuia there are fifteen or more papillae of which two pairs (one adanal and one postanal) are subdorsal or lateral in position. In Heth there are thirteen to fifteen papillae depending on whether or not the adanal lateral pair (presumably papilla 4) is present. In Rondonema, Carnoya and Ransomnema there are thirteen caudal papillae, the adanal sublateral pair being absent.

\section{- Spicules and Gubernaculum}

The primitive state is two similar and equal, convergent spicules and a gubernaculum.

In the Rhigonematoidea there are two convergent spicules but the gubernaculum is reduced or absent. Spicules are similar and equal in the Rhigonematidae and in Paraichthyocephalus, but they are dissimilar in Ichthyocephalus and Ichthyocephaloides.

Spicules are similar and parallel (not convergent) in the Carnoyidae. A gubernaculum is present in all genera but reduced in Raonema. In Ransomnema spicules are convergent and dissimilar ; the gubernaculum is absent and its role is assumed by the left spicule. Spicules are convergent and fused in Heth.

- Miscellaneous Structures.

A ventral sucker occurs in males of Ransomnema and Heth. This structure was also reported in the original description of Clementeia but Kloss (1956) suggested that Artigas (1930) had mistaken a male of Heth for one of Clementeia. Little is known about the anatomy of Clementeia and this suggestion awaits confirmation.

In Urucuia the ventral cuticle on the caudal extremity of the male bears reinforced striations which presumably aid in holding the female during copulation. In males of Brumptaemilius there is a prominent area rugosa. 


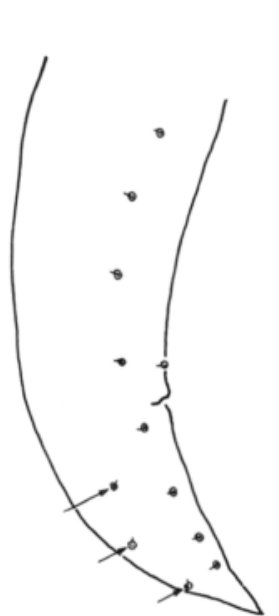

A
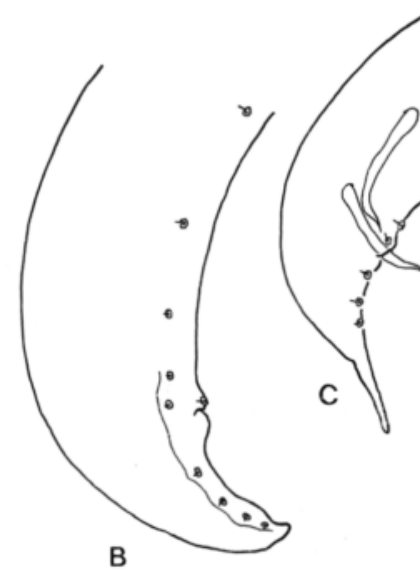

8
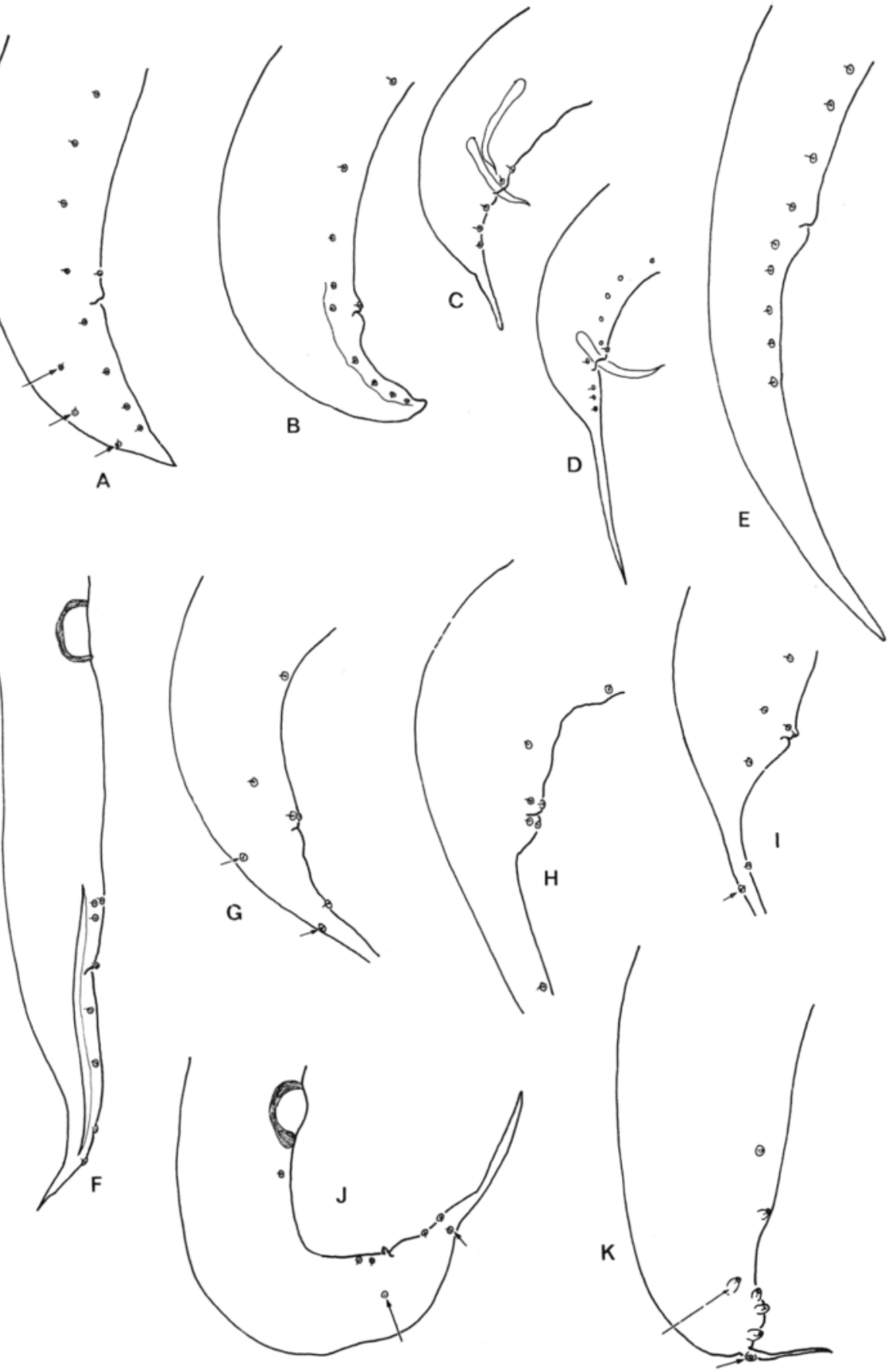

FIG. 5. - Variation in male caudal morphology in the Rhigonematida.

A to $\mathrm{E}$ : Rhigonematoidea : A, African Rhigonema and Obainia; $\mathbf{B}$, New World Rhigonema C, Rhigonema from New Zealand Sphaeroteroidea (Glomerida) ; D, Glomerinema from Madagascar Sphaeroteroidea; E, Ichthyocephaloides. Note presence of subdorsal papillae in A (arrows) and similarity between $\mathrm{C}$ and $\mathrm{D}$.

$\mathrm{F}$ to $\mathrm{K}$ : Ransomnematoidea : F, Ransomnema ; G, Waerebekeia ; H, Carnoya ; I, Rondonema ; J, Heth; K, Brumptaemilius. Note presence of sublateral to subdorsal papillae (arrows): two in $G$, $\mathrm{J}$ and $\mathrm{K}$, one in $\mathrm{I}$ and nine in $\mathrm{F}$ and $\mathrm{H}$. 


\section{Modifications of the External Cuticle}

- Cephalic Modifications ( fig. 6)

Tiny transverse striations occur on the cuticle of most Nematoda and can be considered a primitive feature of both superfamilies considered here. Primitively striations begin immediately posterior to the lip region but in the Rhigonematoidea the cuticle of the cephalic extremity is devoid of striations and forms a smooth cap. In the Rhigonematidae the cephalic cap is accompanied by a posterior collar separated from the cap by a deep groove ; the posterior edge of the collar forms a prominent overhang and striations beging posterior to it. The cuticle of the cephalic extremity forms a smooth cap in three genera of the Carnoyidae, namely, Urucuia, Waerebekeia and Raonema.

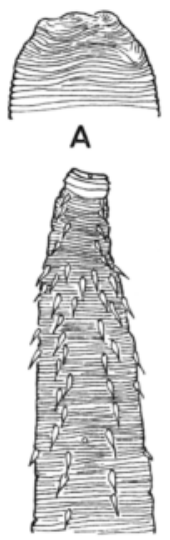

B

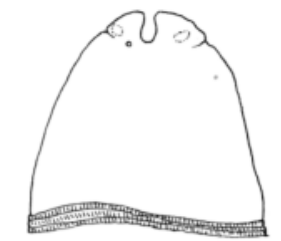

C

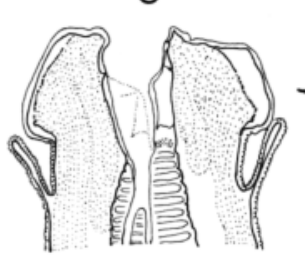

D

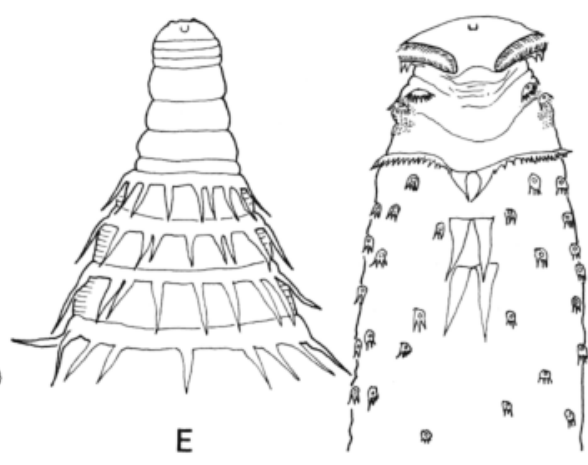

F
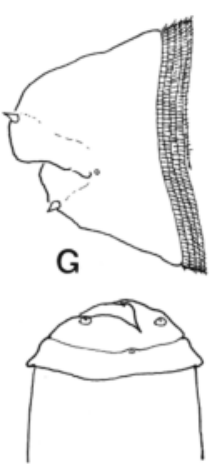

$\mathrm{H}$

FIG. 6. - Modifications of the external cuticle in the Rhigonematida.

A, male and B, female Brumptaemilius; C, male Waerebekeia; D, male Urucuia; E, female Carnoya; F, female Heth; G, Ichthyocephalus showing cephalic cap. ; H, Rhigonema with cephalic cap and collar.

\section{- Annulations}

Annulations are deep transverse grooves which may be separated by one or more striations. They have arisen in many parasitic nematodes and occur in three genera of the Carnoyidae : Brumptaemilius, Raonema and Carnoya. In the first two genera they occur only in females.

- Spines

In the Rhigonematoidea spines are arranged in transverse rows, each row corresponding to a stria. Spines are generally more pronounced anteriorly and may become scale-like or disappear posteriorly. Such spination may assist in anchoring the worm between folds of the intestine. Spines are secondarily absent in a number of South American species of Rhigonema considered by Travassos and Kloss (1959) to comprise the genus Ruizia. 
A number of different spination patterns occur in the Ransomnematoidea. The type of spination is characteristic of a given genus but little can be concluded from the absence of spines and the character is therefore of limited value beyond the species level.

Rows of tiny spines occur on the striae of females of certain Brumptaemilius and Waerebekeia. In other Brumptaemilius large spines are arranged in several longitudinal rows in the oesophageal region ; similar spination occurs in Raonema and Urucuia. In Rondonema spines are restricted to the lateral region and are apparently anterior modifications of the lateral alae. In Carnoya spines are arranged in a series of spiny collars in the oesophageal region; the more anterior collars represent annules but posteriorly annules are absent and spines are smaller and less regularly disposed. Females of Heth exhibit a variety of spine-like formations including isolated simple spines, comb-like or button-like compound spines, and spiny collars.

\section{Biological considerations}

Very little is known of the biology of rhigonematids. We know that they must be monoxenous since they are restricted to the Diplopoda which feed entirely on decaying vegetation. We report here on some observations previous authors or ourselves have made on the biology of the group. Life history tactics in the two rhigonematid superfamilies are apparently different.

The Rhigonematoidea are generally large worms which produced large numbers of thick-shelled eggs. Some authors (Leidy, 1853 ; Clark, 1978) have observed them attached to the intestinal wall of the host by their jaw apparatus. Rhigonema infecta in southern Canada are wedged in large numbers in the sphincter region between mid-and hindgut, with their anterior extremities projecting into the midgut. We have observed Ichthyocephalus wedged between folds in the intestinal wall. Parasitic females in this superfamily deposit eggs at about the four-cell stage; these pass to the external environment, larvate and are then presumably infective.

The Ransomnematoidea are commonly less than $3 \mathrm{~mm}$ long and live unattached in the lumen of the hindgut. Primitively, females produce small numbers of large thin-shelled eggs which do not develop beyond the four-cell stage in the parasitic female. We have not observed egg deposition in such females ; females of Heth mauriesi isolated from the host and placed in aged tap water remain active for up to two weeks, during which time their eggs larvate. We do not know whether such eggs are infective or if larva must hatch and undergo further development in the external environment. Female Brumptaemilius are among the largest ransomnematoids; they produce large numbers of thick-shelled eggs which they deposit readily in tap water. The eggs larvate and hatch spontaneously presumably releasing infective larvae. 


\section{Cladistic representation}

For each character used we have defined a primitive state (0) and one or more evolved states $(1,2,3, \ldots ;-1,-2,-3, \ldots)$. Negative numbers are used to indicate a second evolutionary direction represented by an encircled number in the cladogram. In legends to the characters used to construct cladograms we give the character number, followed by a description of its various states with their evolutionary score in parentheses.

The Rhigonematida are placed in the class Rhabditea (sensu Inglis, 1983) characterized by the following synapomorphies : buccal capsule consisting of a cheilostome, protostome and telostome, and males with ten paired and one unpaired caudal papillae of which three pairs are lateral in position. The order is characterized by the following : the posterior portion of the buccal capsule consists of a telostome fused with part or all of the protostome, and is surrounded by oesophageal tissue; the vagina is long and heavily muscled. The Rhigonematida is divided into two superfamilies which have apparently evolved in quite different directions and which may be descendants of distinct parasitic events.

\section{Rhigonematoidea ( fig. 7)}

The superfamily is characterized by the following : presence, at least primitively, of spines ; cephalic extremity in form of cephalic cap with or without posterior collar ; oesophageal corpus robust ; protostome and telostome fused, completely surrounded by oesophageal tissue ; terminal duct of excretory system vesiculate ; egg with thick, smooth shell.

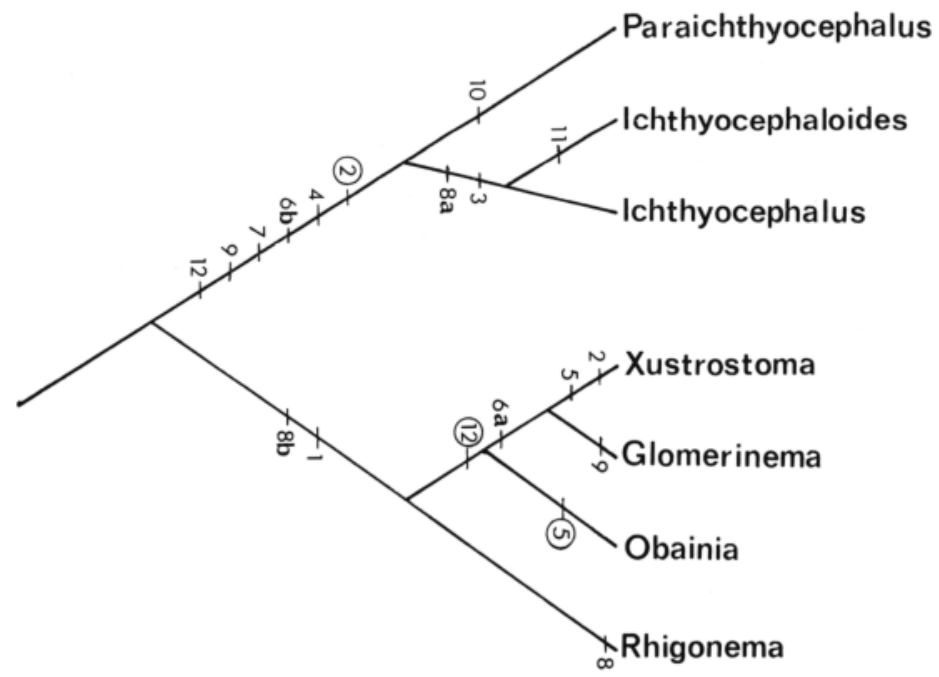

FIG. 7. - Cladogram to genera of the Rhigonematoidae. Synapomorphies are indicated by slash marks and identified by a number (see text for legend). Encircled numbers indicate a second evolutionary series. $6 \mathrm{~b}$ and $8 \mathrm{~b}$ are more evolved than $6 \mathrm{a}$ and $8 \mathrm{a}$. 
1. Cephalic collar absent (0), present (1).

2. Oral opening in form of equal sided triangle (0), dorsoventrally elongate (1), laterally elongate $(-1)$.

3. Spicules similar (0), dissimilar (1).

4. Buccal capsule in form of three articulating pieces $(0)$, in form of one dorsal and one ventral plate (1).

5. Dorsal jaw-piece similar to subventral piece (0), dissimilar and well-developed (1), dissimilar and reduced $(-1)$.

6. Jaw-pieces with tooth-like excrescences (0), with spine rows (1).

7. Submedian outer cephalic papillae mammiliform (0), conical (1).

8. Oesophageal isthmus longer than width of bulb (0), about half as long as bulb width (1), less than half as long as bulb width but forming distinct cylindrical portion (2), represented only by constriction between corpus and bulb (3).

9. Three sublateral to subdorsal papilla pairs present (0), subdorsal and sublateral papillae pairs absent (1).

10. Spicules without (0), with (1) surface sculpturing.

11. Female reproductive system didelphic (0), monodelphic (1).

12. Oesophageal corpus clavate and long (0), ovoid (1), much shorter than bulb (-1).

Ransomnematoidea ( $f \mathrm{~g} .8$ )

The superfamily is characterised by the following : reduced number of caudal

FIG. 8. - Cladogram to genera of the Ransomnematoidea. Synapomorphies are indicated by slash marks and identified by a number (see text for legend). Encircled numbers indicate a second evolutionary series. Ib, $3 b, 8 b, 13 b$ and $17 b$ are more evolved than $1 a, 3 a, 8 a$, I 3 a and $17 a$.

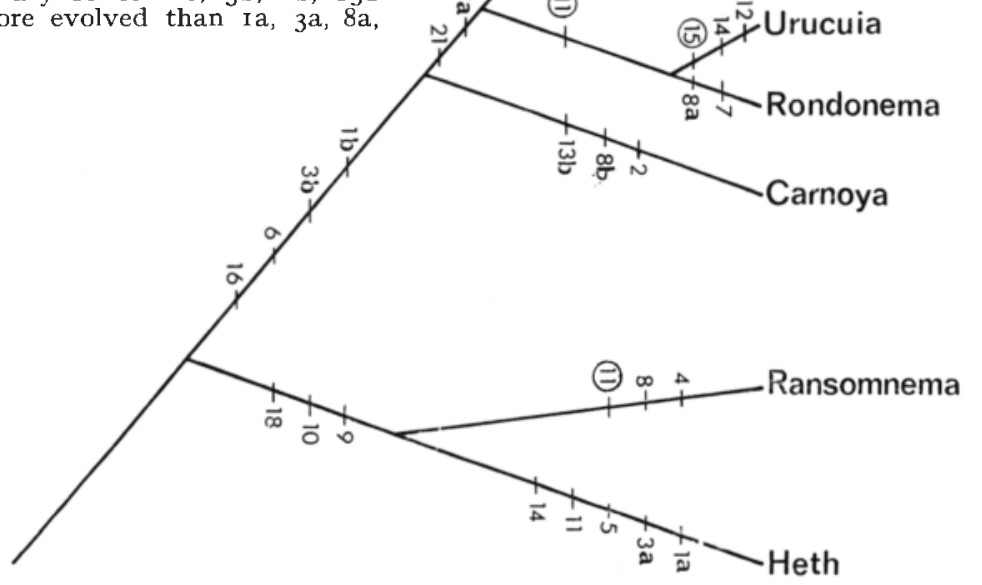


papillae ; monodelphy; presence, primitively of three pennate cuticular metastomal projections; corpus primitively spindle-shaped and sharply demarcated from isthmus and bulb.

1. Oesophageal corpus spindle-shaped in both sexes (0), spindle shaped in male, cylindrical in female (1), spindle shaped in male, divided in female (2).

2. Protostome urceolate in male (0), long and tubular in male (1).

3. Metastomal projections present in both sexes, of Ransomnema-type (0), developed only in male, of Ransomnema-type (1), reduced in both sexes (2), developed only in male, Brumptaemilius-type (-1).

4. Spicules similar (0), dissimilar (1).

5. Spicules separate (0), fused (1).

6. Spicules convergent (0), parallel (1).

7. Number of caudal papillae : fifteen or more $(0)$, thirteen (1).

8. Subdorsal or sublateral caudal pipalla pairs : two (0), one (1), none (2).

9. Vulva about half way between cephalic extremity and anus $(0)$, vulva markedly posterior (1).

10. Spermatids subspherical (0), elongate (1).

11. Lips of male : one dorsal and two subventral (0), one dorsal and one ventral (1), Lips absent $(-1)$, one ventral and two subdorsal $(-2)$.

12. Cephalic cap absent (0), present (1).

13. Annulations absent (0), present in female (1), present in both sexes (2).

14. Tail of male tapering gently form anus (0), subulate (1), abruptly truncate with caudal appendage (2).

15. Area rugosa absent (0), ventral striae reinforced in caudal region of male $(-1)$, present (1).

16. Outer submedian cephalic papillae of female non-salient (0), forming subspherical saliences (1).

17. Egg shell thin and flexible (0), thin and inflexible (1), thick and with surface sculpturing (2).

18. Ventral sucker absent (0), present (1).

19. Spicules smooth $(0)$, with surface sculpturing (1).

20. Gubernaculum well-developed, subtriangular in lateral view (0), reduced, dorsoventrally flattened (1).

21. Vagina directed posteriorly from vulva $(0)$, anteriorly from vulva (1).

\section{Host and geographical distribution}

\section{RHIGONEMATOIDEA}

Ichthyocephalids occur essentially in South American Rhinocrididae (Spirobolida). However, the monotypic Ichthyocephaloides comes from an unidentified New Guinea diplopod (Hunt and Sutherland, 1984) and the family may be more widely distributed in the Pacific region. 
The Rhigonematidae are known from all southern continents and North America. Xustrostoma and Glomerinema occur in the Sphaeroteroidea (Glomerida) in Madagascar and the only described species of Obainia comes from Pachybolus sp. in Gabon. Over 35 species of Rhigonema have been described from Africa, North and South America, Australia, New Zealand, India, Malaysia and Polynesia. This genus includes the most primitive of the rhigonematoids and they occur in all of the host groups parasitized by the superfamily. African and Indian forms resemble Obainia and Xustrostoma in disposition of postanal caudal papillae, i.e. they possess three pairs lateral to subdorsal (Adamson, 1983d ; Adamson and van Waerebeke, 1984b). Forms from New Zealand and Sumatran Sphaeroteroidea (Parona, 1896 ; Clarke, 1978) resemble Madagascan Glomerinema, also from the Sphaeroteroidea (van Waerebeke, 1985a, 1985b) in disposition of caudal papillae as well as in general form of the male tail and spicules. Thus, Rhigonema may represent a paraphyletic group of primitive forms of several lineages of the Rhigonematidae.

RanSOMNEMATOIDEA

Ransomnematoids are known from the Polydesmida, Spirobolida and Spirostreptida but none has been reported from the Glomerida. The Hethidae and Ransomnematidae are most common in South American Rhinocricidae although species of Heth occur in the Polydesmida and other are known from the Pacific region. The Carnoyidae can be divided into two branches : one African/Indian and the other from South America and the Pacific. Most Brumptaemilius spp. have been described from African Spirostreptida although the genus is probably also common in African Spirobolida. The monotypic Waerebekeia comes from a spirostreptid from Malawi and Raonema occurs in Indian Spirostreptida.

Carnoya is the most widely distributed carnoyid and occurs in South America and the Pacific region; most species come from the Rhinocricidae. The monotypic Urucuia is from a Brazilian spirostreptid. Rondonema spp. have been described from several unidentified diplopods and from Pseudonannolenou tricolor (Spirobolida), all in South America.

\section{Systematic affiliations of the Rhigonematida with other parasitic Nematoda}

As mentioned above, we consider the Rhigonematida to belong to the Rhabditea. Two other parasitic orders of this class have been affiliated with rhigonematids at one time or another, namely the Ascaridida and the Oxyurida. The fundamental distinctness of the Oxyurida and the Rhigonematida has been treated in earlier articles (Adamson, 1981 ; Adamson and van Waerebeke, 1984) and we will not repeat the arguments here. However, Chitwood (1950a) placed some rhigonematids (the Ransomnematoidea in our classification) in the Atractidae (Ascaridida) and Inglis (1983) has condidered rhigonematids as a suborder of the Ascaridida. Inglis gave no 
morphological justifications for his decision and we argue here that the only similarities between rhigonematids and ascarids are plesiomorphic characters : oesophagus consisting of corpus, isthmus and valved bulb; presence of two spicules; relatively unreduced number of caudal papillae, etc. Such characters give us no information concerning phylogenetic relationships beyond the fact that both groups evolved from rhabditid like ancestors.

Presumed synapomorphies of the Ransomnematoidea and some primitive Ascaridida (especially the Atractidae) are due to convergence. Thus monodelphy of ransomnematoids has little in common with that of atractids. In the latter group there is one ovary; thin shelled eggs larvate and hatch in utero and play a role in a highly evolved endogenous (autoinfective) cycle. In ransomnematoids, ovaries and oviducts are paired. The thin shelled eggs do not develop beyond the four cell stage in the parasitic female. They embryonate in the external environment and are presumably a primitive element in an exogenous cycle. Similarly the ventral sucker of the Ransomnematoidea has little in common with that of the Cosmocercoidea.

In summary, the Rhigonematida, Ascaridida and Oxyurida are considered distinct orders of the class Rhabditea. We cannot say whether rhigonematids are more closely related to oxyurids or to ascarids but Inglis (1983) separates the Oxyurida (subclass Rhabditia) from the rhigonematids and ascarids which he places in the subclass Diplogasteria.

\section{BIBLIOGRAPHIE}

Adamson M. L. : Rhigonema infecta (Leidy, I849) Christie and Cobb, I927 and the systematic position of the Rhigonematidae sensu Theodorides, I965. Syst. Parasitol., I98I, 3, 209-2 I 7.

Adamson M. L. : Two new species of Heth Cobb, I 898 (Nematoda ; Rhigonematidae) from South American diplopods. Bull. Mus. Natn. Hist. Nat., $4^{\mathbf{e}}$ sér., I982, 4, 405-4 8.

Adamson M. L. : The genus Ransomnema Artigas, 1926 (Rhigonematidae) in South American diplopods. Syst. Parasitol., I983a, S, II9-I 25.

Adamson M. L. : Redescriptions of Rondonema rondoni Artigas, 1926 and $R$. pseudonannolenou Dollfus, 1952 and a revision of Rondonema Artigas, I 926. Syst. Parasitol., I983b, s, I 75-1 84.

Adamson M. L. : Redescriptions of five species of Heth Cobb, I 898 (Rhigonematidae; Nematoda) from South American diplopods. Syst. Parasitol., I983c, 5, I $85-202$.

Adamson M. L. : Obaina gabonensis n. gen., n. sp. and Rhigonema pachyboli n. sp. (Rhigonematidae; Nematoda) from Pachybolus sp. (Pachybolidae; Spirobolida; Diplopoda ; Myriapoda) in Gabon. Bull. Mus. Natn. Hist. Nat., $4^{\mathrm{e}}$ sér., I $983 \mathrm{~d}, 5,53 \mathrm{I}-542$.

ADAMSON M. L. : Ichthyocephalus seymouri n. sp. and a redescription of Ichthyocephalus ichthyocephalus Artigas, 1926 (Rhigonematidae; Nematoda). Proc. Helm. Soc. Wash., I983e, so, 294-300.

ADAMSON M. L. : Brumptaemilius gabonensis n. sp. (Ransomnematinae; Rhigonematidae; Nematoda) from Pachybolus sp. (Spirobolida; Diplopoda) from Gabon with comments on the Ransomnematinae. Bull. Mus. Natn. Hist. Nat., $4^{\mathrm{e}}$ sér., I983f, $5,75^{8-766 .}$

Adamson M. L. : A revision of Carnoya Gilson, I 898 (Nematoda; Rhigonematidae) with descriptions of four new species. Syst. Parasitol., I984a, 6, I I 3-1 29.

Adamson M. L., Anderson N. H. : Rhigonematid (Nematoda) parasites of Archispirostreptus tumuliporus (Spirostreptida; Diplopoda) in Malawi. Can.J.Zool., 1985 (in press).

AdAMSON M. L., Van WAEREBEKE D. : Cytological aspects of gametogenesis in two rhigonematid (Nematoda) parasites of Anadenobolus politus (Porat) (Rhinocricidae; Diplopoda) from Guadeloupe. Can. J. Zool., I984a, 62, I90-192.

Adamson M. L., Van WAEREBEKE D. : Carnoya kermarreci n. sp. (Rhigonematidae; Nematoda) from Anadenobolus politus (Porat) (Rhinocricidae; Diplopoda) from Guadeloupe. Syst. Parasitol., I985, 7, 27-32.

Adamson M. L., Van WAEREBEKe D. : Xustrostoma mavgarettae n. gen., n. sp. (Rhigonematidae; Nematoda) from a sphaeroteroid (order Glomerida) diplopod in Madagascar. Can. J. Zool., I $984 \mathrm{~b}, 62,2092-2096$. 
Adamson M. L., Zaman V. : Metastomal projections in Brumptaemilius gabonensis Adamson, I983 (Ransomnematinae; Nematoda) : their distribution in the subfamily and possible function. I. Parasitol., I984, 70, 239-242

Chabaud A.-G., Petter A. J. : Remarques sur l'évolution des papilles clocales chez les Nématodes phasmidiens parasites de Vertébrés. Pavassitologia, I96I, 3, 5I-70.

CHIrwood B. G. : A synopsis of the nematodes parasitic in insects of the family Blattidae. Z. Parasitenkde, $1932,5, \mathrm{I}_{4}^{-50}$.

Chitwood B. G. : General structure of nematodes. In : Introduction to Nematology (edited by B. G. and M. B. Chitwood). Monumental Printing Co., Baltimore, U.S.A., I950a, 7-27.

Chitwoon B. G. : Cephalic structures and stoma. In : Introduction to Nematology (edited by B. G. and M. B. Chitwood). Monumental Printing Co., Baltimore, U.S.A., I95ob, 56-77.

Clark W. C. : New species of rhigonematid and thelastomatid nematodes from the pill millipede Procyliosoma tuberculata (Diplopoda; Oniscomorpha), N.Z. J. Zool., I978, 5, I-6.

Dollfus R.-P. : Quelques Oxyuroidea de Myriapodes. Ann. Parasitol. Hum. Comp., I952, 27, I 43-236.

FüllEBORN F. : On the larval migration of some parasitic nematodes in the body of the host and its biological significance. $J$. Helminthol., I929, 7, I 5-26.

Hunt D. H., Sutherland J. A. : Ichthyocephaloides dasycanthus n. gen., n. sp. (Nematoda; Rhigonematoidea) from a millipede from Papua, New Guinea. Syst. Parasitol., I984, 6, I 4II 46 .

Inglis W. G. : An outline classification of the Nematoda. Austr. I. Zool., 1983, 3I, 243-255.

Kloss G. R. : Organizaçao filogenetica dos Nematoides intestinais de Artropodos. Atas Soc. Biol., Rio de Janeiro, I960, 4, 52-55.

Kloss G. R. : Compêndio dos Nematoides parasitos intestinais de Artropodos. III. Carnoyidae e Hethidae. Arq. Zool., 1965, I3, 47-I 37 .

LEIDY J. : Flora and fauna within living animals. Smithson. Contr. Knowt., I853, 5, I-67.

Osche G. : Die Bursa - und Schwarzstructuren und ihre Aberrationen dei den Strongylina (Nematoda), morphologische Studien zur Problem der Pluri- und Parapotenzerscheinungen. Z. Morph. Okol. Tieve, I958, 46, 57I-635.

Osche G. : Systematische, morphologische und parasitophyletische Studien an parasitischen Oxyuroiden (Nematoda) exotischer Diplopoden (ein Beitrag zur Morphologie der Sexualdimorphismus). Zool. Jb., Abt. Syst. Okol. Geogr. Tieve, I960, 87, 395-440.

Parona C. : Di alcuni Nematodi dei Diplopodi. Bol. Mus. Zool. Anat. Comp. R. Univ. Genova, I $896,44, \mathrm{I}-6$.

PoInAR G. O. : CIH Key to groups and genera of nematode parasites of invertebrates. Commonwealth Agricultural Bureaux, Farnham Royal, Bucks., England, I977, I-43.

Poinar G. O. : Mesidionema praecomasculatus gen. et sp. n. ; Mesidionematidae fam. n. (Drilonematoidea ; Rhabditida) a nematode parasite of earthworms. Proc. Helm. Soc. Wash., I978, $45,97^{-102}$.

Rao P. N., Kumari M. M. : A description of a new species of the genus Rondonema Artigas, 1926 with comments on the allied genera. Riv. Parassitol., I967, 28 , I I-I6.

Skrjabin K. I., Schikhobalova N. P., Lagodovskaya E. A. : [Oxyurids of invertebrates.] Nauka, Moscow, I966, $53^{8} \mathrm{p}$. [in Russian].

Travassos L., Kloss G. R. : Sobre a familia Rhigonematidae (Artigas, 1930). Atas Soc. Biol. Rio de Janeiro, 1959,3, 9-1o.

Travassos L., Kloss G. R. : Compêndio dos Nematoides parasitos intestinais de Artropodos. I. Cephalobiidae, Robertiidae e Rhigonematidae. Arq. Mus. Nac., 1960, 50, 237-303.

Travassos I., Kloss G. R. : Compêndio dos Nematodes parasitos intestinais de Artropodos. II. Ichthyocephalidae e Ransomnematidae. Avq. Mus. Nac., I965, 53, 55-83.

Van WAEREBEKE D. : Rhigonema madecassum n. sp. (Rhigonematidae; Nematoda) parasite de Diplopode à Madagascar : description et étude de la spermiogenèse. Rev. Nematol., I984, 7 , $267-282$.

Van WAEREBEKE D. : Glomerinema ratsimamangi n. gen., n. sp. (Nematoda, Rhigonematidae) parasite de Glomeris (Diplopoda) à Madagascar : description et spermiogenèse. Ann. Parasitol. Hum. Comp., I985a, 60, 23-32.

Van WAEREBEKE D. : Trois nouvelles espèces de Glomerinema van Waerebeke, I984 (Rhigonematidae, Nematoda) parasites de Sphaeroteroidea (Glomerida : Diplopoda) à Madagascar. Rev. Nematol., I985b (in press).

Van Waerebeke D., Adamson M. L., Kermarrec A. : Spermiogenèse et fonction du sac vaginal chez Ichthyocephalus anadenoboli n. sp. (Rhigonematidae ; Nematoda), parasite d'Anadenobolus politus (Porat) (Rhinocricidae; Diplopoda) en Guadeloupe. Ann. Parasitol. Hum. Comp., I984, s9, IOI-IO9. 